\title{
Perbandingan Kualitas Produk Sayur Dan Buah Pada Pasar Tradisional Dan Pasar Modern Di Kota Serang Dalam Penerapan Strategi Pamasaran
}

\author{
Khaeruman ${ }^{1}$, Hafidz Hanafiah ${ }^{2}$ \\ Program Studi Manajemen, Universitas Bina Bangsa Banten \\ E-mail: ${ }^{1}$ khaeruman.oce@gmail.com, ${ }^{2}$ magoo_blank@yahoo.com
}

\section{ARTICLE INFO}

Keywords:

Product Quality,

Traditional and Modern

Markets,

Target Strategy

\section{ABSTRACT}

Agricultural products are types of products that have disadvantages, among others: perishable and short shelf life, especially for horticulture. These weaknesses cause horticultural products to require special treatment from pre-harvest to post-harvest so that the quality does not decrease. A decrease in product quality will affect its sale value in the market. However, special handling requires additional costs, so the amount of post-harvest handling must also consider the demand of the buyer.

This research aims to find out and understand the best storage treatment for fruits and vegetables to maintain the physical condition of the products and marketing strategies in traditional and modern markets.

Based on the results of research shows that most of the people of Serang City tend to prefer shopping in traditional markets, but most also choose to shop in traditional and modern markets, in their opinion it can be concluded that if they shop at traditional markets they can bargain from prices that have been set and they can also directly, whereas if in the modern market they can only see the prices available on the desired goods.

\section{PENDAHULUAN}

\section{Latar Belakang}

Produk pertanian merupakan jenis produk yang mempunyai kelemahan antara lain : mudah rusak dan daya simpan yang pendek, terlebih lagi untuk hortikultura. Kelemahan-kelemahan inilah yang menyebabkan produk hortikultura membutuhkan perlakuan khusus mulai dari pra panen hingga pasca panen agar kualitasnya tidak menurun. Penurunan kualitas produk akan mempengaruhi nilai jualnya di pasar. Namun penanganan khusus membutuhkan biaya tambahan, sehingga besarnya penanganan pasca panen harus mempertimbangkan pula permintaan pembeli.

Tiap pembeli mempunyai permintaan yang berbeda terhadap produk yang dibeli. Bagi pembeli tingkat atas, pertimbangan lebih ke kualitas daripada harga sehingga petani dapat menjual dengan harga lebih tinggi yang tentu saja dengan akibat adanya biaya tambahan untuk penanganan agar kualitasnya sesuai. Sedangkan pembeli bawah pertimbangan lebih ke harga sehingga petani dapat menjual produknya tanpa tindakan penanganan yang membutuhkan biaya tentu dengan akibat kualitas produksi tidak sebaik produk yang ditangani secara maksimal.

Berbagai tindakan penanganan pasca panen yang dilakukan oleh petani berfungsi untuk menghambat laju kebusukan atau mempercepat pemasakan produk. Pada buah umumnya petani memanfaatkan keberadaan $\mathrm{C}_{2} \mathrm{H}_{4}$ atau etilen yang bermanfaat mempercepat proses pemasakan dan keseragaman tingkat pemasakan. $\mathrm{C}_{2} \mathrm{H}_{4}$ atau Etilen bisa berasal dari buah itu sendiri atau dari sumber yang lain. Sedangkan pada sayuran petani justru berusaha mempertahankan tingkat kesegaran sayuran yang dijual engan cara menghambat laju kehilangan air pada jaringan sayuran yang dapat menyebabkan layu. Cara-cara yang sering dijumpai antara lain penyiraman air secara berkala dan penyimpanan pada suhu rendah. Demikian pula pada tanaman hias, petani dalam mempertahankan kualitas produknya juga memperlakukan secara khusus. Kegiatan yang umum dilakukan adalah merendam pangkal batang yang dipotong ke air, baik air biasa maupun yang diberi tambahan bahan lain. Fungsi dari kegiatan ini adalah untuk mempertahankan tingkat kesegaran produk hingga pembeli. 
Dalam menghadapi persaingan pasar-pasar modern dalam era globalisasi saat ini setiap pasarpasar tradisional dituntut untuk dapat bersaing dengan pasar-pasar modern yang berkembang kian cepat baik. Kehadiran pasar modern, terutama supermarket dan hypermarket dianggap oleh berbagai kalangan telah menyudutkan keberadaan pasar tradisional di perkotaan.

Penyimpanan buah dan sayuran segar dapat memperpanjang umur panen suatu komoditi dan dalam keadaan dapat tertentu memperbaiki kualitas produk; di samping itu juga menghindarkan banjirnya produk ke pasar, memberi kesempatan yang luas untuk memilih buah-buahan dan sayursayuran sepanjang tahun, membantu pemasaran yang teratur, meningkatkan keuntungan produsen, dan mempertahankan mutu produk-produk yang masih hidup. Tujuan utama penyimpanan adalah pengendalian laju transpirasi, respirasi, infeksi penyakit, mempertahankan produk dalam bentuk yang paling berguna bagi pembeli.

Peningkatan daya simpan bertujuan untuk mempertahankan kesegaran dari suatu komoditi dengan kata lain menjaga agar kandungan gizinya tidak menurun karena layu atau rusak mutu tetap baik. Komoditi yang akan disimpan harus seragam kematangannya dan harus dibungkus dengan kantong atau karung untuk menghindari menjalarnya penyakit. Lama penyimpanan masing-masing komoditi tidak sama tergantung kondisi fisik suatu produk (Rahardjo, 1993).

\section{Tujuan Penelitian}

Setelah melaksanakan kegiatan ini diharapkan untuk mengetahui dan memahami perlakuan penyimpanan yang terbaik bagi buah dan sayuran untuk mempertahankan kondisi fisik produk serta strategi pemasaran pada pasar tradisional dan pasar modern.

\section{LANDASAN TEORI}

\section{Kualitas Produk}

Kualitas adalah kombinasi antara karakteristik yang menentukan nilai produk terhadap pembeli. Kondisi buah dan sayuran segar berkaitan dengan penampilan, kualitas sensoris, rasa dan kualitas nutrisinya. Pembeli menilai kualitas buah dan sayuran segar berdasarkan penampilan dan ketegaran. Tingkat pembelian pembeli bergantung pada pengalaman konsumsi kosumen, ditambah kualitas dan keamanan nutrisi.

Kualitas visual buah dan sayuran berhubungan dengan ukuran, bentuk, warna, kemulusan , kebersihan permukaan dan tidak adanya cacat atau tanda pembusukan. Cacat produk segar meliputi: memar dan hancurnya potongan, mengkerut dan layu akibat kehilangan air, jamur atau pelunakan jaringan, perubahan warna akibat pencoklatan enzimatik atau gangguan fisik, kelembutan dan perendam air akibat penuaan.

Bahaya kimia meliputi zat alami (misalnya alergen, mycotoxins, alkaloid dan penghambat enzim), produk kimia (misalnya pestisida, desinfektan air), zat terlarang (misalnya beberapa pestisida, metil bromida) dan unsur toksik (misalnya timah, kadmium, arsenik, seng). Efek buruknya pada kesehatan manusia bisa dampak langsung dan tidak langsung terhadap dan juga berdampak pada lingkungan, flora dan fauna, dan dampak pada kesehatan pekerja pedesaan. Bahaya kimiawi dapat dikenalkan pada buah dan sayuran segar selama produksi (misalnya produk fitosanitasi, pupuk, antibiotik, zat pengatur tumbuh, dan lain-lain) dan penanganan pasca panen.

\section{Pasar Tradisional dan Pasar Modern}

\section{a. Pasar Tradisional}

Pasar dapat diartikan sebagai tempat pembeli dan penjual barang tertentu berhubungan satu sama lain dan terjadi hubungan tukar menukar daerah perniagaan dan suatu daerah yang secara ideal harga-harga pada waktu tertentu adalah sama untuk semua pembeli dan penjual.

Pasar tradisional merupakan tempat bertemunya penjual dan pembeli serta ditandai dengan adanya transaksi penjual pembeli secara langsung dan biasanya ada proses tawar-menawar, bangunan biasanya terdiri dari kios-kios atau gerai, los dan dasaran terbuka yang dibuka oleh penjual atau pengelola pasar.

\section{b. Pasar Modern}

Pasar moderen adalah pasar yang dikelola dengan manajemen moderen, umumnya terdapat di perkotaan, sebagai penyedia barang dan jasa dengan mutu dan pelayanan yang baik kepada pembeli yang pada umumnya anggota masyarakat kelas menengah ke atas. Pasar modern antara lain mall, 
supermarket, department store, shopping center, waralaba, toko mini swalayan, pasar serba ada, dan toko serba ada (Irawan, 2007).

Pasar modern tidak banyak berbeda dari pasar tradisional, namun pada pasar jenis ini penjual dan pembeli tidak bertransaksi secara langsung melainkan pembeli melihat label harga yang tercantum dalam barang (barcode), berada dalam bangunan dan pelayanannya dilakukan secara mandiri (swalayan) atau dilayani oleh pramuniaga. Barang yang dijual memiliki jenis yang beragam. Selain barang lokal, pasar moderen juga menyediakan barang impor, barang yang dijual juga mempunyai kualitas yang relatif lebih terjamin karena melalui penyeleksian yang ketat.

\section{c. Efisiensi Pasar Tradisional dan Pasar Modern}

Efisiensi pemasaran merupakan ukuran yang digunakan oleh banyak pakar dan peneliti pemasaran dalam menganalisis saluran pemasaran suatu produk. Faktor-faktor yang memengaruhi efisiensi pemasaran suatu produk diantaranya adalah jarak antara produsen (petani) kepada pembeli, ukuran pasar atau jumlah komoditi yang diperdagangkan, persentase produk di pasar, luas areal panen, dan jumlah penduduk (Silitonga, 1999).

\section{d. Strategi Pemasaran}

Definisi pemasaran menurut American Marketing Association (AMA) seperti dikutip oleh Kasali (Malidia, 2012), adalah suatu proses perencanaan dan eksekusi, mulai dari tahap konsepsi, penetapan harga, promosi, hingga distribusi barang-barang, ide-ide dan jasa, untuk melakukan pertukaran yang memuaskan individu dan lembaga-lembaganya. Soekartawi (Heryadi, 2011), mengatakan bahwa saluran pemasaran adalah saluran atau jalur yang digunakan, baik secara langsung maupun tidak langsung untuk memudahkan pemilihan suatu produk itu bergerak dari produsen sampai berada di tangan pembeli.

Buah-buahan dan Sayuran merupakan salah satu komoditas hortikultura yang penting bagi perekonomian Indonesia. Sayuran memiliki karakteristik yang mudah rusak sehingga lembaga pemasaran yang terlibat di dalamnya dituntut untuk melakukan aktivitas pemasaran yang tepat sehingga kualitas sayuran tetap terjaga. Adapun lembaga pemasaran sayuran terdiri dari petani, pedagang pengumpul, pedagang besar, pedagang pengecer (Silitonga 1999; Permana 2004), serta eksportir dan pembeli institusi untuk pasar modern (Setiawan 2009).

Analisis pemasaran sayuran telah banyak dilakukan oleh peneliti baik di Indonesia maupun luar negeri. Sayuran tersebut diantaranya wortel, kentang, kubis (Silitonga 1999; Setiawan 2009). Pada dasarnya saluran pemasaran sayuran yang terjadi memiliki kemiripan satu sama lain dimana melibatkan lembaga pemasaran yang hampir sama. Secara khusus, saluran pemasaran sayuran di Banten bermuara kepada pembeli luar negeri dan pembeli domestik yang bergerak dari desa menuju ke daerah perkotaan.

Adapun pasar tradisional umumnya dipasarkan melalui pedagang pengecer. Pasar modern umumnya memasok sayuran dari pedagang besar (wholesaler) dan tidak langsung dari petani. Berdasarkan penelitian terdahulu di beberapa Negara berkembang, sedikit sekali petani yang mampu mengakses saluran tersebut secara langsung, terutama petani kecil. Hal ini disebabkan adanya persyaratan volume produksi yang harus berkelanjutan dan kualitas yang harus konsisten. Oleh karena itu, saluran pasar modern membentuk saluran tersendiri dengan melibatkan lembaga pemasaran yang berbeda dengan saluran pasar tradisional.

\section{METODOLOGI PENELITIAN}

Metode penelitian pada dasarnya merupakan cara ilmiah untuk mendapatkan data dengan tujuan dan kegunaan tertentu. Penelitian ini penulis mempergunakan pendekatan penelitian kualitatif. Lokasi penelitian adalah di Kota Serang Provinsi Banten. Lokasi tersebut memberikan kemudahan akses sehingga memudahkan peneliti dalam memperoleh data lapangan yang akan berlangsung selama 3 bulan waktu efektif, dimulai bulan Maret sampai dengan Mei 2019.

Metode penelitian pada dasarnya merupakan cara ilmiah untuk mendapatkan data dengan tujuan dan kegunaan tertentu. Metode yang digunakan dalam Kajian ini adalah metode evaluasi formatif yaitu melihat dan mengkaji pelaksanaan serta program, mencari umpan balik untuk memperbaiki pelaksanaan program yang dimaksud, (Sinagarimbun dan Sofian Efendi, 2008:41). Guna menganalisis perbandingan kualitas produk sayur dan buah pada pasar tradisional dan pasar modern di Kota Serang dalam penerapan strategi pamasaran. Metode penelitian pada dasarnya menggunakan metode survei. Survei adalah penelitian yang

Khaeruman, et.al. (Perbandingan Kualitas Produk Sayur Dan Buah Pada Pasar Tradisional...) 
mengambil sampel dari salah satu populasi sebagai alat pengumpulan data yang pokok (Singarimbun dan Effendi, 1995:23).

Penelitian kualitatif cenderung menggunakan teknik cuplikan atau sampling yang bersifat selektif dengan menggunakan pertimbangan berdasarkan konsep teoritis yang digunakan. Dengan kata lain teknik sampling adalah teknik yang digunakan untuk menyeleksi atau memfokuskan permasalahan agar pemilihan sampel lebih mengarah pada tujuan penelitian. Pada penelitian ini tidak menentukan jumlah sampel, tetapi peneliti menentukan sejumlah informan untuk diwawancarai guna memperoleh informasi tentang permasalahan yang sedang diteliti.

\section{PEMBAHASAN}

\section{Pengolahan Data}

a. Perbandingan Pasar Modern Dengan Pasar Tradisional Keputran

\begin{tabular}{|c|c|c|c|}
\hline No & Uraian & Pasar Modern & Pasar Tradisional \\
\hline 1 & Pengertian & $\begin{array}{l}\text { Pasar modern tidak banyak } \\
\text { berbeda dari pasar } \\
\text { tradisional, namun pasar } \\
\text { jenis ini penjual dan pembeli } \\
\text { tidak bertransksi secara } \\
\text { langsung melainkan pembeli } \\
\text { melihat label harga yang } \\
\text { tercantum dalam barang } \\
\text { (barcode), berada dalam } \\
\text { bangunan dan pelayanannya } \\
\text { dilakukan secara mandiri } \\
\text { (swalayan) atau dilayani oleh } \\
\text { pramuniaga. Barang-barang } \\
\text { yang dijual, selain bahan } \\
\text { makanan makanan seperti; } \\
\text { buah, sayuran, daging; } \\
\text { sebagian besar barang } \\
\text { lainnya yang dijual adalah } \\
\text { barang yang dapat bertahan } \\
\text { lama. }\end{array}$ & $\begin{array}{l}\text { Pasar tradisional merupakan } \\
\text { tempat bertemunya penjual } \\
\text { dan pembeli serta ditandai } \\
\text { dengan adanya transaksi } \\
\text { penjual pembeli secara } \\
\text { langsung dan biasanya ada } \\
\text { proses tawar-menawar, } \\
\text { bangunan biasanya terdiri } \\
\text { dari kios-kios atau gerai, los } \\
\text { dan dasaran terbuka yang } \\
\text { dibuka oleh penjual maupun } \\
\text { suatu pengelola pasar. } \\
\text { Kebanyakan menjual } \\
\text { kebutuhan sehari-hari seperti } \\
\text { bahan-bahan makanan berupa } \\
\text { ikan, buah, sayur-sayuran, } \\
\text { telur, daging, kain, dan lain- } \\
\text { lain }\end{array}$ \\
\hline 2 & Harga Barang & $\begin{array}{l}\text { Barang-barang yang dijual } \\
\text { di pasar tradisional dan } \\
\text { pasar modern memiliki } \\
\text { perbedaan harga yang } \\
\text { cukup signifikan. Harga } \\
\text { suatu barang di pasar } \\
\text { tradisional bahkan bisa } \\
\text { sepertiga dari harga barang } \\
\text { yang sama yang dijual di } \\
\text { supermarket, terutama } \\
\text { untuk produk-produk segar } \\
\text { seperti sayur-sayuran serta } \\
\text { bumbu-bumbu dapur. }\end{array}$ & $\begin{array}{l}\text { Barang-barang yang dijual di } \\
\text { pasar tradisional dan pasar } \\
\text { modern memiliki perbedaan } \\
\text { harga yang cukup signifikan. } \\
\text { Harga suatu barang di pasar } \\
\text { tradisional bahkan bisa } \\
\text { sepertiga dari harga barang } \\
\text { yang sama yang dijual di } \\
\text { supermarket, terutama untuk } \\
\text { produk-produk segar seperti } \\
\text { sayur-sayuran serta bumbu- } \\
\text { bumbu dapur. }\end{array}$ \\
\hline 3 & Tawar-menawar & $\begin{array}{l}\text { Sedangkan di pasar modern, } \\
\text { pembeli tidak mungkin } \\
\text { melakukan tawar menawar } \\
\text { karena semua barang telah } \\
\text { dipatok dengan harga pas. }\end{array}$ & $\begin{array}{l}\text { Berbelanja di pasar } \\
\text { tradisional memungkin-kan } \\
\text { pembeli untuk menawar } \\
\text { harga barang-barang hingga } \\
\text { mencapai kesepakatan }\end{array}$ \\
\hline
\end{tabular}

Khaeruman, et.al. (Perbandingan Kualitas Produk Sayur Dan Buah Pada Pasar Tradisional...) 


\begin{tabular}{|c|l|l|l|}
\hline & & & dengan pedagang. \\
\hline 4 & Diskon & $\begin{array}{l}\text { Pada pasar modern diskon } \\
\text { secara besar-besaran. }\end{array}$ & $\begin{array}{l}\text { Tidak pernah ada } \\
\text { pemberitahuan ketika ada } \\
\text { diskon. }\end{array}$ \\
\hline 5 & $\begin{array}{l}\text { Kenyamanan } \\
\text { Berbelanja }\end{array}$ & $\begin{array}{l}\text { Kesegaran Produk } \\
\text { yang lebih luas, bersih, rapi, } \\
\text { dan dilengkapi dengan } \\
\text { pendingin ruangan }\end{array}$ & $\begin{array}{l}\text { Sedangkan pasar tradisional } \\
\text { menempati area yang lebih } \\
\text { sempit, sumpek, sesak, dan } \\
\text { tak jarang menguarkan bau } \\
\text { kurang sedap. }\end{array}$ \\
\hline $\begin{array}{l}\text { Produk-produk yang yang } \\
\text { ada di pasar modern sebagian } \\
\text { besar sudah terindikasi zat- } \\
\text { zat pengawet. Dengan modal } \\
\text { yang besar supermarket } \\
\text { mampu mempeli pasokan } \\
\text { produk lebih banyak. Dengan } \\
\text { demikian, mereka } \\
\text { menggunakan zat-zat } \\
\text { pengawet untuk } \\
\text { mengawetkan persediaan } \\
\text { barang. }\end{array}$ & $\begin{array}{l}\text { Untuk produk-produk segar, } \\
\text { sayur-sayuran, buah-buahan, } \\
\text { dan lain sebagainya, pasar } \\
\text { tradisional biasanya } \\
\text { menyajikan produk yang jauh } \\
\text { lebih segar ketimbang } \\
\text { supermarket, karena belum } \\
\text { ditambahkan zat pengawet. }\end{array}$ \\
\hline
\end{tabular}

\section{b. Proses Keputusan Pembelian Pembeli Sayuran dan Buah-buahan di Pasar tradisional dan} modern

1) Pengenalan Kebutuhan

Proses pengenalan kebutuhan pada sayuran dimulai sejak manusia di lahirkan didunia, karena sayuran dan buah-buahan merupakan bahan makanan yang memiliki kandungan gizi yang baik dan sangat berguna bagi kesehatan tubuh. sayuran dan buah-buahan merupakan bahan makanan yang bisa dikonsumsi oleh segala usia. Kesadaran akan kandungan nilai gizi dan manfaat dari sayuran dan buah-buahan tersebut membuat pembeli mencari dan mengkonsumsi sayuran dan buah-buahan, seseorang jika merasa butuh akan sesuatu maka sesuatu itu akan dianggap penting begitu pula dengan mengkonsumsi sayuran dan buah-buahan. Karena mengetahui manfaat dari sayuran dan buah-buahan maka seseorang itu merasa butuh untuk mengkonsumsi sayuran dan buah-buahan sehingga dianggap penting untuk di konsumsi.

2) Evaluasi Alternatif dan Proses Pembelian

Setelah mendapatkan informasi yang cukup tentang hal-hal yang berkaitan dengan pasarpasar di Kota Serang, maka pembeli akan melakukan evaluasi alternatif. Evaluasi alternatif di definisikan sebagai suatu proses di mana suatu alternatif di evaluasi dan di pilih untuk memenuhi kebutuhan pembeli. Pada tahap ini pembeli menentukan kriteria yang relevan dengan keinginannya untuk dapat membuat suatu keputusan yang di rasa paling bermanfaat untuk memecahkan masalahnya.

\section{c. Potensi Pasar Tradisional dan Pasar Modern di Kota Serang}

Keberadaan pasar tradisional dari satu sisi memang banyak kekurangan seperti lokasinya yang kadang mengganggu lalulintas, kumuh, kurang tertata, dan lain-lain. Pasar tradisional memegang peran yang cukup penting dalam perekonomian, mengingat bahwa sebagian besar masyarakat masih mengandalkan perdagangan melalui pasar tradisional. Sehingga sudah selayaknya pemerintah Kota Serang memperhatikan eksistensi pasar tradisional tersebut, sehingga sesuai dengan tujuan dalam melaksanakan pembangunan ekonomi yaitu untuk meningkatkan pendapatan sehingga tercapai kesejahteraan. 
1) Wawancara dengan Pembeli

Menurut hasil wawancara dengan Ibu Irma pada tanggal 16 Mei 2019 beliau menjelaskan bahwa beliau kesehariannya berbelanja di pasar tradisional dibandingkan pasar modern, karna menurut beliau apabila berbelanja dipasar tradisional dengan membawa uang Rp 50.000 beliau sudah mendapatkan berbagai macam sayuran seperti : Cabai, Rampai, sayuran serta lauk pauk sedangkan apabila dipasar modern menurutnya belum tentu mendapatkan itu semua dan dengan kualitas yang sama.

Menurut Ibu Yati lebih suka untuk berbelanja harian dipasar tradisional seperti sayuran dan buah-buahan, karna menurut beliau apabila beliau membeli sayuran dan buah-buahan dipasar modern itu sudah tidak alami dari petani langsung melainkan sudah diberi obat, sedangkan untuk bahan-bahan lainnya.

Menurut Ibu Rika lebih cendrung berbelanja di pasar modern karena selain bermasalah dengan waktu apabila dipagi hari yang begitu padat beliau juga menganggap harga dipasar tradisional dan pasar modern sama saja karna semua yang diperjual belikan adalah barang yang sama melainkan kemasan yang berbeda apabila dipasar tradisional itu tidak tertata (tersusun rapih) sedangkan dipasar modern itu tertata rapih.

2) Wawancara dengan Pedagang

Menurut wawancara dengan bapak Hendra pada tanggal 16 Mei 2019 menjelaskan bahwa awal berdagang pasar tahun 2007, sebelumnya beliau adalah seorang buruh bangunan dan pekerja serabutan pada tahun 2007 beliau mulai berdagang sembako dan kebutuhan pokok lainnya dan yang membuat beliau berdagang dipasar Rau Kota Serang adalah karna diberi kesempatan oleh pemerintah daerah untuk berbelanja dipasar Rau Kota Serang dan untuk member nafkah keluarga.

Untuk strategi pemasaran yang beliau berikan kepada konsumen yaitu dengan member harga sedikit lebih murah dibandingkan pedagang lainya, seperti hal diwarung beliau harga gula pasir Rp. 12.800 sedangkan ditoko pesaingnya yaitu mencapai harga Rp. 13.000 jadi dari strategi yang beliau terapkan tersebut beliau mampu mempertahankan langganannya hingga sekarang bahkan untuk sekarang beliau ingin menambah kembali toko karena permintaan barang sembako untuk toko beliau semakin banyak.

Menurut ibu Sari Imah menjelaskan bahwa berdagang dari tahun 2000. Sebelum berdagang sayur-sayuran beliau menjadi ibu rumah tangga yang membuat beliau berdagang dipasar Kalodran adalah kebutuhan ekonomi keluarga karena suami hanya seorang petani disawah. Dalam penetapan harga yang ibu Sari Imah berikan kepada konsumen dibilang cukup rendah dibandingkan harga yang ditetapkan penjual lainnya, karena dalam penetapan harga ibu Sari Imah memiliki prinsip tidak masalah mendapatkan untung sedikit tetapi pembeli akan terus berbelanja terhadapnya dari pada mendapatkan untung banyak tetapi konsumen hanyasekali membeli. Untuk strategi promosi yang ibu Sari Imah berikan yaitu dengan strategi mendapatkan untuk sedikit asalkan konsumen menjadi langganan terhadap barang apa yang beliau tawarkan kepada pembeli.

\section{d. Strategi Pemasaran}

\section{Analisis 3C's (Company, Costumers, and Competitors)}

1) Organisasi Perusahaan (Company)

Pasar Tradisional, tempat masih dikelola UD Pasar yang merupakan perusahaan BUMD yang tidak berorientasi profit hanya sebatas menyediakan sayur dan buah agar masyarakat dapat menikmatinya, akan tetapi untuk para pedagangnya masih melakukan perdagangannya secara tradisional.

Pasar Modern dimiliki oleh swasta yang lebih berorientasi profit. Sehingga semua dilakukan secara terencana terorganisasi serta berfokus kepada kepuasan pelanggan.

2) Pelanggan (Costumers)

Costumer adalah pelanggan yang berarti orang-orang yang membeli psroduk atau jasa yang kita jual. Kita harus bisa menjadikan potensi market yang ada diluar sana menjadi costumer kita. Karena diluar sana begitu banyak potensi market yang mungkin akan menjadi costumer kita. Untuk menarik potensi market menjadi costumer kita harus memberikan solusi atas permasalahan yang dihadapi. 
Sebagai mana kita ketahui keinginan setiap potensi costumer beragam, sebagai pengusaha kita harus bisa membaca itu semua, salah satunya yaitu dengan membuat Empahty Map. Emphaty Map ini adalah untuk mengetahui apa yang dirasakan, diinginkan dan dilakukan pelanggan kita.

Pasar Tradisional, para pedagang menyediakan sayur dan buah tidak menggunakan emphaty map. Kostum seadanya, kadang senyum kadang tidak. Kepuasan pelanggan bukan tujuan sebenarnya. Yang penting bagaimana sayur dan buah saya terjual dengan baik.

Pasar Modern melakukan emphaty map, pegawai yang senyum, wangi, rapi, siap membantu. Sehingga akan timbul rasa kepuasan pelanggan. Meskipun harganya lebih tinggi yang harus dibayarkan dibandingkan pasar tradisional.

2) Pesaing (Competitors)

Setiap bisnis yang dijalankan pasti akan menghadapi persaingan, baik itu bisnis yang baru ataupun sudah berjalan lama. Persaingan akan semakin ketat ketika produk kita semakin dikenal dipasar, karena akan semakin banyak kompetitor produk kita. Bagaimana kita bisa bertahan di persaingan pasar yang semakin ketat, tentunya produk kita harus mempunyai keunggulan yang dibutuhkan pembeli.

Menurut Michael Porter ada lima hal yang harus kita perhatikan, yaitu:
a) Pendatang baru
b) Barang Substitusi / Pengganti
c) Supplier
d) Pembeli / Pembeli
e) Persaingan Industri

\section{Analisis SWOT (Strengths, Weaknesses, Opportunities, Threaths)}

Menurut Kotler (2000), pengertian lingkungan pemasaran suatu perusahaan terdiri dari pelaku atau kekuatan-kekuatan yang mempengaruhi kemampuan perusahaan untuk mengembangkan dan mempertahankan transaksi yang menguntungkan dengan para pelanggan sasaran.

\section{1) Analisis Lingkungan Internal}

Analisis lingkungan internal pada dasarnya mencakup dua aspek, yaitu kekuatan (strength) dan kelemahan (weakness). Faktor-faktor internal perusahaan meliputi semua fungsi manajamen operasional, antara lain: pemasaran, keuangan, operasional, SDM, penelitian dan pengembangan, sistem informasi manajemen, serta budaya perusahaan.

\section{2) Analisis Lingkungan Eksternal}

Analisis lingkungan eksternal adalah upaya untuk melakukan identifikasi dan analisis terhadap berbagai faktor lingkungan luar perusahaan, seperti pengaruh perkembangan ekonomi, politik, hukum, ekologi, teknologi, kependudukan, sosia budaya dan lingkungan industri, yang mempunyai pengaruh terhadap kebijakan perusahaan. Analisis lingkungan eksternal pada dasarnya mencakup dua aspek, yaitu peluang (Opportunity) dan ancaman (Threat).

\begin{tabular}{|c|c|c|}
\hline & $\begin{array}{l}\text { Kekuatan (S) } \\
\text { 1. Keuletan pedagang } \\
\text { 2. Hubungan baik antara } \\
\text { pedagang dan pembeli } \\
\text { 3. Tenaga kerja } \\
\text { 4. Promosi melalui teknologi } \\
\text { informasi } \\
\text { 5. Proses labelisasi kemasan } \\
\text { 6. Pelayanan pesan antar bagi } \\
\text { pembeli } \\
\text { 7. Kualitas produk } \\
\text { 8. Penggunaan teknologi } \\
\text { sederhana } \\
\text { 9. Hubungan baik dengan } \\
\text { pemasok }\end{array}$ & $\begin{array}{l}\text { Kelemahan (W) } \\
\text { 1. Tumpang tindih sayur } \\
\text { buah } \\
\text { 2. Belum ada pemisahan } \\
\text { 3. Belum memiliki } \\
\text { jaringan distribusi yang } \\
\text { kontinu } \\
\text { 4. Keterbatasan modal } \\
\text { usaha } \\
\text { 5. Administrasi dan } \\
\text { pencatatan keuangan } \\
\text { masih sederhana }\end{array}$ \\
\hline $\begin{array}{l}\text { Peluang }(\mathrm{O}) \\
\text { 1. Pertumbuhan jumlah }\end{array}$ & $\begin{array}{l}\text { Strategi }(\mathrm{S}-\mathrm{O}) \\
\text { 1. Menjalin kerjasama yang }\end{array}$ & $\begin{array}{l}\text { Strategi }(\mathrm{W}-\mathrm{O}) \\
\text { 1. Memanfaatkan kredit }\end{array}$ \\
\hline
\end{tabular}




\begin{tabular}{|c|c|c|}
\hline $\begin{array}{l}\text { penduduk } \\
\text { 2. Pola konsumsi sayur dan } \\
\text { buah } \\
\text { 3. Tradisi belanja } \\
\text { 4. Dukungan pemerintah } \\
\text { konsumsi sayur buah } \\
\text { 6. Perkembangan teknologi } \\
\text { informasi. } \\
\text { 7. Ketersediaan pemasok } \\
\text { yang cukup banyak }\end{array}$ & $\begin{array}{l}\text { kontinu dengan pemasok bahan } \\
\text { baku dan dinas terkait guna } \\
\text { memperoleh bahan baku } \\
\text { berkualitas dan pemasaran } \\
\text { produk } \\
\text { 2. Meningkatkan diversifikasi } \\
\text { produk sayur dan buah }\end{array}$ & $\begin{array}{l}\text { yang ditawarkan oleh } \\
\text { pemerintah untuk } \\
\text { pengembangan usaha } \\
\text { 3. Membangun jaringan } \\
\text { distribusi produk untuk } \\
\text { menjangkau segmentasi } \\
\text { pasar yang lebih luas }\end{array}$ \\
\hline $\begin{array}{l}\text { Ancaman }(\mathrm{T}) \\
\text { 1. Fluktuasi harga bahan } \\
\text { baku } \\
\text { 2. Hambatan masuk rendah } \\
\text { 3. Ancaman produk } \\
\text { substitusi } \\
\text { 4. Tingkat persaingan antar } \\
\text { industri sedang }\end{array}$ & $\begin{array}{l}\text { Strategi (S-T) } \\
\text { 1.Meningkatkan kualitas dan } \\
\text { inovasi produk agar dapat } \\
\text { bersaing dipasaran } \\
\text { 2. Meningkatkan pelayanan } \\
\text { kepada pembeli }\end{array}$ & $\begin{array}{l}\text { Strategi }(\mathrm{W}-\mathrm{T}) \\
\text { 1. Melakukan perbaikan } \\
\text { dalam pengelolaan dan } \\
\text { pengalokasian } \\
\text { keuangan } \\
\text { 2. Restrukturisasi } \\
\text { organisasi perusahaan }\end{array}$ \\
\hline
\end{tabular}

\section{Analisis STP (Segmentation, Targeting, Positioning)}

1) Segmentation

Menurut Kotler dan Amstrong (2008:225), segmentasi pasar merupakan pembagian pasar menjadi kelompok-kelompok pembeli yang lebih kecil dengan kebutuhan, karakteristik, atau perilaku berbeda yang mungkin memerlukan produk atau bauran pemasaran tersendiri. Kotler dan Armstrong (2008:226), ada empat variabel utama yang bisa digunakan sebagai dasar-dasar pengelompokkan pasar yaitu variabel demografi, geografi, psikografi, dan perilaku.

Dikarenakan penduduk Kota Serang heterogen, maka untuk segmentasi sayur dan buah pasar tradisional kebanyakan masyarakat asli yang berbelanja sayur dan buah. Sedangkan masyarakat pendatang akan berbelanja di pasar modern.

2) Targeting

Targeting berhubungan erat dengan adanya media yang dapat digunakan untuk menjangkau kelompok atau segmen baru. Targeting mempunyai dua fungsi sekaligus yaitu menyeleksi pasar sasaran sesuai dengan kriteria-kriteria tertentu (selecting) dan menjangkau pasar sasaran tersebut (reaching) untuk mengkomunikasikan nilai (Kasali, 2011:371). Target pasar (targeting) adalah persoalan bagaimana memilih, menyeleksi, dan menjangkau pasar. Produk dari targeting adalah pasar sasaran (target market), yaitu satu atau beberapa segmen pasar yang akan menjadi fokus kegiatan-kegiatan pemasaran (Kasali, 2011:371).

Pasar tradisional umumnya para pembeli yang konsen dengan harga. Sedangkan pasar tradisional modern biasanya pembeli yang peduli akan higienis sayur dan buah.

3) Positioning

Positioning merupakan suatu kegiatan merancang penawaran dan citra perusahaan untuk menduduki tempat khusus di benak target pasar yang dituju (Kotler dan Keller, 2009:53). Untuk positioning pasar tradisional biasanya untuk kalangan besar seperti katering, hotel maupun rumah makan. Serta kebanyakan orang yang biasa menawar dengan para pedagang dan ini menjadi ciri khas dari pasar Rau, Kalodran, dan Royal sebagai suatu tradisi nenek moyang. Adanya komunikasi antara pedagang dan pembeli. Sedangkan positioning pasar modern, kebanyakan untuk masyarakat para pekerja yang sibuk dalam karir, para penghuni rumah komplek, serta para pembeli yang tidak mau pusing dengan becek dan susah parkir ketika berbelanja di pasar tradisional. Kebanyakan dari pembeli akan berbelanja pada malam hari.

\section{Analisis 4P (Price, Product, Place, Promotion)}

1) Harga (Price)

Penetapan harga yang dilakukan oleh pelaku usaha didasarkan pada besarnya biaya produksi. Secara umum, tidak ada ukuran pasti untuk setiap sayur dan buah per kilogram. 
Untuk pasar tradisional, harga mengikuti pola supply dan demand. Jika ketersediaan sayur dan buah tinggi, maka harga relatif normal, namun jika ketersediaan sayur dan buah rendah dikarenakan ada kendala misalnya faktor cuaca, maka harga bisa tinggi. Sedangkan untuk kebutuhan sayur dan buah tinggi, maka harga bisa tinggi, namun jika kebutuhan sayur dan buah rendah, maka harga relatif normal.

Hal ini pernah terjadi ketika Pasar Rau, Pasar Lama, dan Pasar Kalodran kekurangan cabai dikarenakan faktor cuaca dari tempat supply kurang baik, maka harga cabai relatif rendah. Umumnya harga sayur dan buah berubah ubah dikarenakan produk sayur dan buah bersumber dari produk lokal. Ini yang menjadi kendala para pedagang kecil dan besar dalam mengontrol harga yang menyesuaikan situasi dan kondisi tertentu.

Untuk pasar modern di Kota Serang seperti Carrefour, Hypermart, dan Ramayana yang tidak hanya berfokus pada sayur dan buah saja. Tetapi menjual menjual berbagai macam jenis barang. Harga relatif stabil karena ketersediaannya bukan tergantung pada produk lokal saja, tetapi juga produk impor.

b) Produk (Product)

Kualitas sayur dan buah pasar tradisional cenderung kurang baik dari segi rasa, ketersediaan, ukuran, kemasan dan variasinya. Para pedagang akan menjual sayur dan buah berdasarkan pedagang besar atau kiriman. Umumnya tidak memiliki legalitas izin dan kualitas produk serta komposisi.

Produk sayur dan buah pasar modern senantiasa mempertahankan kualitas produk dan pelayanan kepada pembeli. Untuk dapat mempertahankan kualitas produknya, sayur dan buah biasanya akan ditempatkan dalam pendingin. Sayur dan buah yang dijual bervariasi dengan produk yang memiliki kualitas yang baik.

Produk sayur dan buah yang dijual terdapat labelisasi kemasan diantaranya merek dagang, izin dari Dinas Kesehatan, P-IRT, komposisi, instruksi penyimpanan dan saran penyajian. Hal ini merupakan kekuatan dari pasar modern yang dimiliki oleh pasar modern membuat pembeli percaya akan produk yang dihasilkan. Disamping upaya untuk terus mempertahankan kualitas produknya, Sayur dan buah juga selalu berupaya mempertahankan pelayanan kepada pembelinya. Upaya mempertahankan pelayanan dilakukan dengan cara membina hubungan baik dengan memberikan variasi sayur dan buah yang sebagian ada yang diimpor.

c) Tempat / Distribusi (Place)

Sayur dan buah pasar tradisional tidak memperhatikan kondisi penjualan, image pasar yang kumuh, banyak lalat, tidak higienis masih mendominasi di pasar tradisional di Kota Serang. Sedangkan distribusi masih tergantung pada pedagang besar atau agen. Sedangkan pasar modern selalu mengutamakan higienis, bersih, berkualitas. Untuk distribusi dikelola dengan baik. Sayur dan buah dikirim langsung oleh produsen dengan perjanjian tertentu dan kualitas yang disepakati. Sehingga proteksi terhadap pembeli terjamin dan aman.

d) Promosi (Promotion)

Pasar tradisional tidak pernah mempromosikan sayur dan buah. Mereka hanya mempunyai pelanggan yang terbiasa membeli. Promosi yang dilakukan oleh sayur dan buah hanya dilakukan melalui informasi mulut ke mulut (word-of-mouth). Tetapi belum mempromosikan melalui media teknologi informasi.

Pasar modern mengkomunikasikannya kepada masyarakat sehingga produk tersebut dikenal dan mereka melakukan pembelian terhadap produk tersebut. Brosur merupakan salah satu strategi yang sebaiknya dilakukan oleh para pengelola pasar modern agar produk sayur dan buahnya dapat dikenal di wilayah Serang dan sekitarnya. Dalam hal ini promosi bisa juga dilakukan melalui Above The Line maupun Below The Line.

\section{Pembahasan dan Analisis}

Kehadiran pasar modern mendorong para pedagang di Pasar Kota Serang untuk memberikan inovasi dalam memberikan layanan kepada para pembeli. Kemudian berupaya mensegmenkan diri kepada masyarakat kelas menengah ke bawah sebagai upaya mencari celah segmen pembeli yang tidak tersaingi oleh kehadiran pasar modern. Ancaman dari pasar modern semakin hari makin gencar menarik pembeli dengan segenap kelebihannya, baik dari segi produk maupun kenyamanan berbelanja. 
a. Dampak Sosial Ekonomi Keberadaan Pasar Modern Pada Pasar Tradisional di Kota Serang

Melalui berbagai wawancara serta pengamatan yang dilakukan oleh peneliti diketahui bahwa dampak lain dari strategi pemasaran dari pasar modern terhadap pedagang Pasar tradisional di Kota Serang adalah meningkatnya daya persaingan di antara para pedagang itu sendiri.

Untuk selanjutnya hasil wawancara dengan salah satu pedagang tradisonal akan diuraikan sebagai berikut: Sedikitnya pedagang itu gak membuat kita jualan makin gampang mas. Kita para pedagang itu malah saingannya tambah berat dengan adanya pasar-pasar modern. Jadi, hubungan antar pedagang itu makin tidak enak. Kalau dulu saingan ya saingan tidak seperti ini, makin banyak pasar-pasar modern.. makin susah jualan. (Hasil wawancara di Pasar RAU dengan Bapak Ridwan, pada tanggal 21 April 2019)

Berdasarkan hasil wawancara di atas menegaskan bahwa makin berkurangnya pembeli pada pedagang di pasar tradisional Kota Serang tidak membuat penjualan makin mudah dan justru memperparah saingan antar pedagang bahkan dengan sama-sama pedagang tradisional itu sendiri.

b. Meningkatnya Persaingan Antar Pedagang Pasar Modern Pada Pasar Tradisional di Kota Serang

Dampak merebaknya pasar modern terhadap persaingan para pedagang Pasar tradisional di Kota Serang secara tidak langsung menyebabkan munculnya konflik antar pedagang yang satu dengan pedagang yang lain di pasar-pasar Kota Serang. Khususnya di pasar tradisional, para pedagang dalam menawarkan produknya pun kerap berlebihan dan seenaknya saja sehingga membohongi pembeli. Sehingga, para pembeli beralih ke pasar modern.

Perubahan sosial dalam hal ini disebabkan karena terlalu banyak kehadiran pasar modern selain dalam penelitian ini seperti Indomaret dan Alfamart yang menyebabkan berbagai perubahan berdampak negatif. Kehadiran pasar modern merupakan input dalam perubahan sosial yang dialami pedagang pasar tradisional Kota Serang.

\section{KESIMPULAN}

Berdasarkan hasil penelitian yang dilakukan penulis di pasar tradisional dan Pasar Modern di Kota Serang bahwa masyarakat cenderung memilih berbelanja dipasar tradisional di karenakan menurut masyarakat adanya sistem tawar menawar, adanya sistem barter dan barang yang diperjual belikan langsung dari petani (khususnya sayuran dan buah-buahan), buka lebih awal dan adanya shering atau saling bertukar informasi antara satu sama lain baik antara pembeli dan penjual, penjual dan penjual maupun pembeli dan pembeli lainnya sedangkan menurut mereka apabila di pasar modern tidak adanya sistem tawar menawar karena harga yang di tetapkan sesuai dengan harga yang tercamtum dalam barcode (lebel) dan apabila dipasar tradisional masyarakat cenderung berinteraksi secara langsung dengan penjual sedangakan dipasar modern masyarakat apabila ingin mengetahui harga dari suatu barang yang di inginkan hanya dapat melihat di barcode (lebel) harga yang tercmtum atau yang tersedia.

Namun apabila di lihat dari segi kenyamanan pasar tradisional khusunya pasar Rau, Pasar Kalodran dan Pasar Lama sangatlah kurang, karena masih banyak msyarakat yang berjualan di sepanjang jalan, lahan parkir yang masih menggunakan jalan dan tempat-tempat berjualan yang masih belum stabil sedangkan apabila dipasar modern memiliki lahan parkir yang luas, keamanan dan kenyamanan yang terjamin dan tempat yang higenis (bersih).

Pembenahan dan penambahan fasilitas pasar perlu di tingkatkan lagi sehingga akan mampu memperluas lapangan pekerjaan dan mengurangi tingkat penganguguran dan meningkatkan kesejahteraan masyarakat.

\section{DAFTAR PUSTAKA}

Heryadi, A, Y. 2011. "Pola Pemasaran Sapi Potong di Pulau Madura". Jurnal Sosial Ekonomi Pertanian. $5(2): 1-8$

Irawan B. 2007. Fluktuasi Harga, Transmisi Harga, dan Marjin Pemasaran Sayuran dan Buah. Analisis Kebijakan Pertanian. 5(4): 358-373

Kotler, Philip. 2000. Prinsip-Prinsip Manajemen Pemasaran. Jakarta : Prenhalindo. 
Kotler, Philip and Gary Armstrong. 2008. Prinsip-Prinsip Pemasaran. Edisi. 12. Jilid 1. Jakarta: Erlangga.

Kasali, Rhenald. 2011. Membidik Pasar Indonesia: Segmentasi, Targeting, dan. Positioning. Jakarta : PT Gramedia Pustaka Utama.

Kotler dan Keller. 2009. Manajemen Pemasaran. Jilid I. Edisi ke 13 Jakarta: Erlangga

Malidia, R. R. 2012. “Analisis strategi pemasaran pada PT. Koko Jaya Prima Makassar. Skripsi. Makassar: Universitas Hasanuddin Fakultas Ekonomi dan Bisnis.

Setiawan AS. 2009. Studi Peningkatan Kinerja Manajemen Rantai Pasok Sayuran Dataran Tinggi Terpilih di Jawa Barat [Tesis]. Bogor (ID): Institut Pertanian Bogor.

Singarimbun, M dan S. Effendi. 1995. Metode Penelitian Survei. LP3ES, Jakarta. , Metode Penelitian Survei, Jakarta: LP3ES, 2008

Silitonga EH. 1999. Analisis efisiensi pemasaran sayuran dataran tinggi kabupaten Karo provinsi Sumatera Utara [Tesis]. Bogor (ID): Institut Pertanian Bogor.

Port, Michael. 2006. Book Yourself Solid. New York : John Wiley Son, Inc.

Porter, Michael E. 1990. Competitive Strategy, Techniques for Analysing Industries and Competitors. New York: The Free Press. 